\title{
STUDI KINETIKA MASKER DAUN ASAM JAWA (Tamarindus indica L.) DALAM MENGHILANGKAN PENYAKIT CACAR
}

\author{
Fadila Maharani \\ Fakultas Matematika Dan Ilmu Pengetahuan Alam \\ Universitas Negeri Padang \\ Jl. Prov Hamka, Air Tawar, Padang, Sumatera Barat
}

Email. Fadila.maharani11@gmail.com

\begin{abstract}
Abstrak
Study ini bertujuan untuk membuat masker daun asam jawa untuk menghilang atau penyembuhan penyakit cacar. Metode yang digunakan adalah eksperimen dan uji aktivitas katalitik secara langsung. Tahapan prtama dilakukan dengan penumbukan dari daun asam jawa. Uji aktivitas langsung dilakukan dengan variasi dengan penghalusan daun asam jawa dan dilakukan $2 \mathrm{x}$ pemakaian dalam sehari. Hasil eksperimen membuktikan bahwa ekstrak daun asam jawa dapat menyembuhkan penyakit cacar. Kondisi optimum ektrak daun jawa tercapai pada 10 hari. Penyembuhan ini diduga karena aktivasi katalitik ekstrak daun asam jawa terhadap penyakit cacar
\end{abstract}

Kata kunci : reaksi kimia, katalis, daun asam jawa, cacar.

\section{PENDAHULUAN}

Reaksi kimia itu pentig untuk kehidupan. Tanpa reaksi kimia dapat terjadi pembusukan. Reaksi kimia dapat terjadi dimana dan kapanpun. Materi yang bereaksi untuk membentuk produk melalui proses disebut reaksi kimia. Tubuh kita hidup dan tumbuh berkat reaksi kimia. Ada reaksi kimia ketika kita meminum obat. Reaksi kimia dapat berlangsung cepat maupun lambat. Reaksi kimia dapat berlangsung cepat karena adanya bantuan katalis [1-8].

Katalis adalah suatu zat yang ditambahkan ke dalam reaksi kimia yang bertujuan untuk mempercepat reaksi kimia[27-35]. Katalis mempercepat reaksi kimia pada suhu tertentu, namun katalis dapat terjadi pada suhu rendah akibat perubahan yang dipicu oleh pereaksi. Penambahan katalis pada suatu reaksi dapat menurunkan energi aktivasi reaksi sehingga reaksi berlangsung lebih cepat. Katalisator mengalami penggabungan dengan senyawa kimia dan membentuk suatu kompleks antara substansi tersebut dengan katalisator[9-17].Katalis dapat mempercepat reaksi-reaksi kimia dalam tubuh makhluk hidup. Katalis alami banyak terdapat diberbagai jenis tumbuhan. Contoh dari katalis alami itu adalah enzim. Pada tumbuhan terdapat berbagai enzim yang dapat berperan dalam mempercepat laju 
reaksi[18-24]. Salah satu contoh tumbuhan yang dapat berperan dalam mempercepat laju reaksi adalah tanama asam jawa [25-26]

Asam jawa adalah jenis buah yang masam rasanya. Biasanya digunakan sebagai bumbu dalam banyak masakan indonesia sebagai penambah rasa pada makanan[45-47]. Asam jawa dihasilkan oleh pohon yang bernama ilmiah Tamarindus indica, termasuk ke dalam suku Fabaceae (Luguminosae).[40-42]

Asam jawa merupakan salah satu tanaman yang banyak ditemukan didaerah tropis. Asam jawa banyak digunakan untuk obat tradisional.Termasuk tumbuhan yang berbuah polon [35-39]. Buahnya bermanfaat dan memiliki efek antimikroba, menurunkan inflamasi, kontrol gula darah[43-44]. Daunnya digunakan sebagai rebusan, dan dapat digunakan untuk pengobatan penyakit campak dan cacar karena memiliki kandungan antibakteri. Kulit biji digunakan untuk menyembuhkan demam. Bijinya dapat digunakan untuk obat luka. Bijinya juga dapat digunakan untuk meningkatkan kualitas air limbah.[48-52]

Cacar merupakan salah satu penyakit yang sering kita jumpai pada anak-anak maupun orang dewasa. Cacar disebakan oleh infeksi virus yang mudah menular. Cacar terdapat pada kulit yang berisi cairan. Cacar terjadi karena sistem imun yang lemah.[53-57]

Berdasarkan informasi dari kampung halaman daun dari asam jawa dapat digunakan untuk penyembuhan penyakit cacar. Ekstrak dan tumbukan dari asam jawa digunakana dalam penelitian ini.

\section{METODE}

\section{Alat dan bahan}

Peralatan yang dipakai adalah lumpang, gelas, sendok, air (SMS) dan bahan yang digunakan adalah daun asam jawa, beras, daun bunga melati.

\section{Penyiapan sampel}

Sampel diambil dari lokasi sicincin, kecamatan 2x11 enam lingkung, kabupaten padang pariaman, provinsi sumatera barat. 


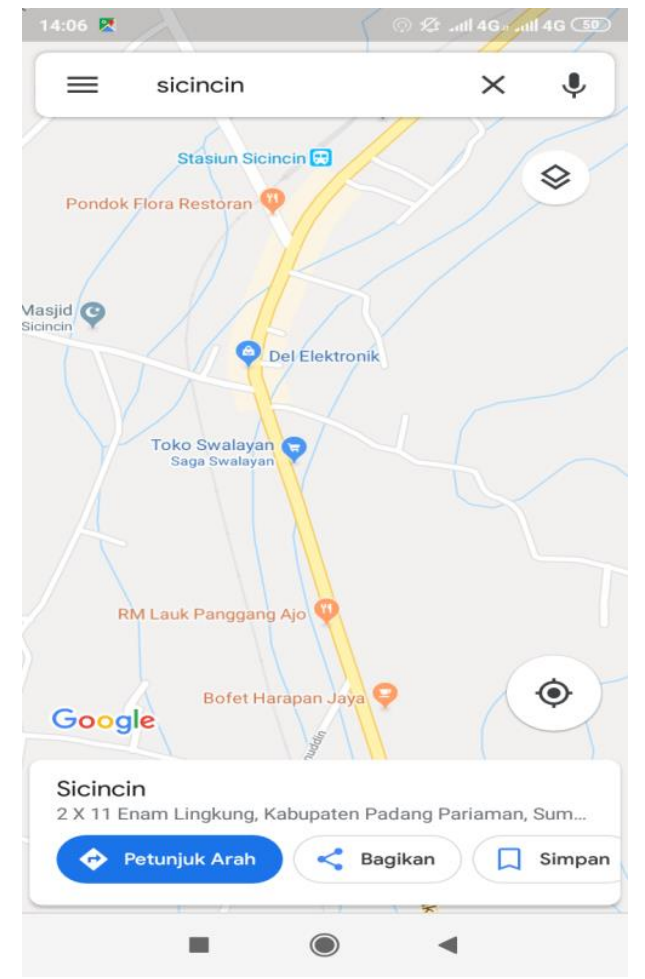

Gambar 1. Lokasi tanaman asam jawa

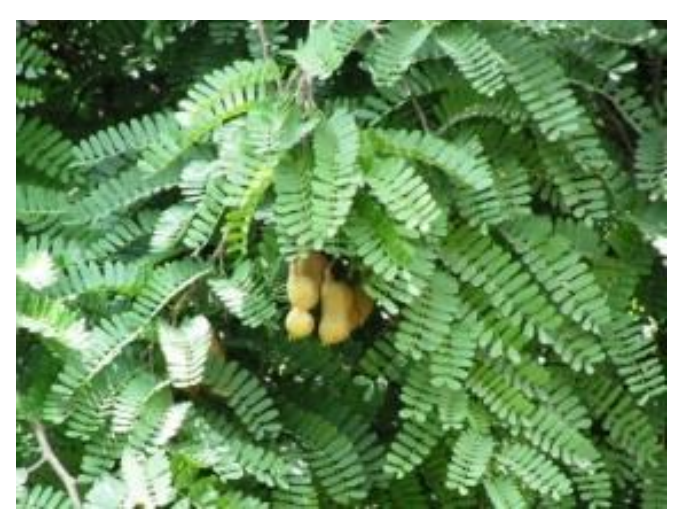

Gambar 2. Daun asam jawa

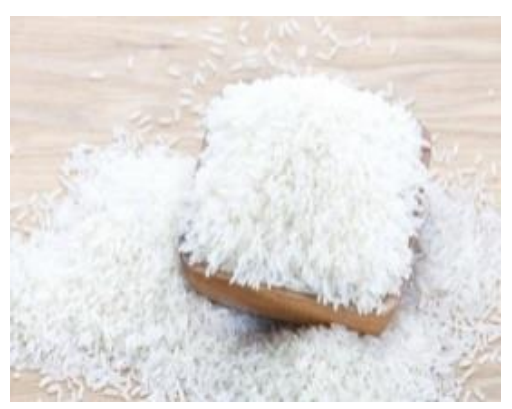

Gambar 3. Beras 


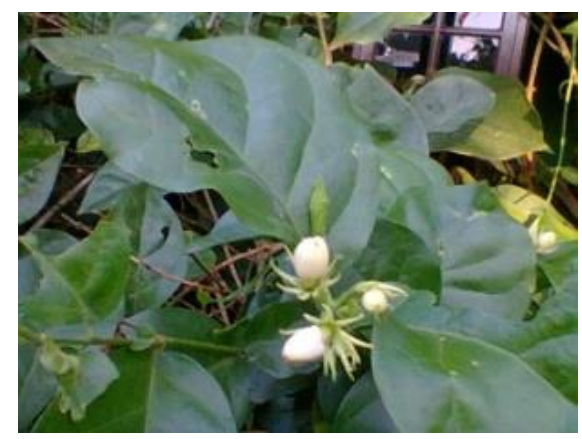

Gambar 4. Daun bunga melati

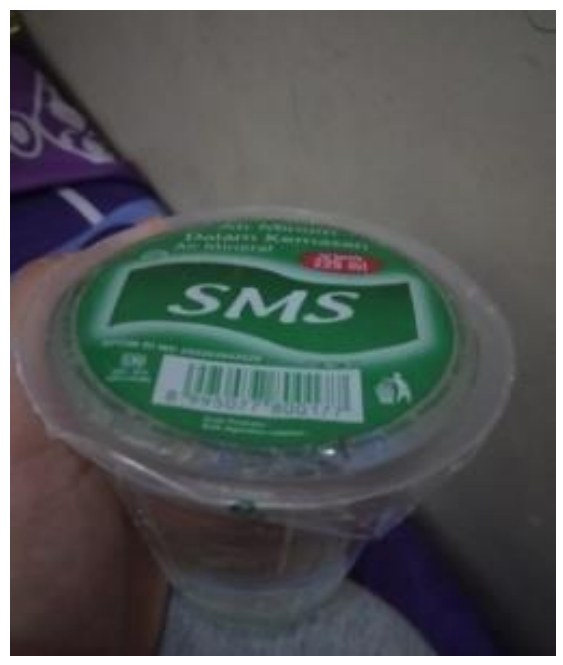

Gambar 5. air

Untuk membuat masker tanaman asam jawa, daun diambil untuk hari pertama sampai hari ketiga cukup menggunakan 1 genggam sampel. Untuk hari ke empat menggunakan 2 genggam sampel. Untuk hari kelima sampai hari kesembilan menggunakan 3 genggam sampel. Untuk hari ke sepuluh menggunakan 4 genggam sampel. Kemudian daun tersebut dimasukkan ke dalam mangkuk untuk melakukan pencucian supaya kotoran atau debu yang mungkin ada di daun tersebut bisa hilang. Setelah daun dicuci, daun asam jawa, beras dan daun melati tersebut dimasukkan ke dalam lumpang dan alu untuk menghaluskannya, dengan penambahan sedikit air. Daun yang sudah halus tersebut diletakkan ke dalam wadah.. Hasil masker daun asam jawa tersebut di pakaikan kepada orang yang terkena cacar. 


\section{Pengujian ekstrak}

Ekstrak yang sudah dihaluskan, dicobakan pada salah seorang yang terkena penyakit cara yang ada di sicincin. Setelah menggunakan masker daun asam jawa ini secara rutin, orang ini mengatakan bahwa cacar mengalami pengurangan.

Metode ini dapat dilihat pada diagram alir berikut:

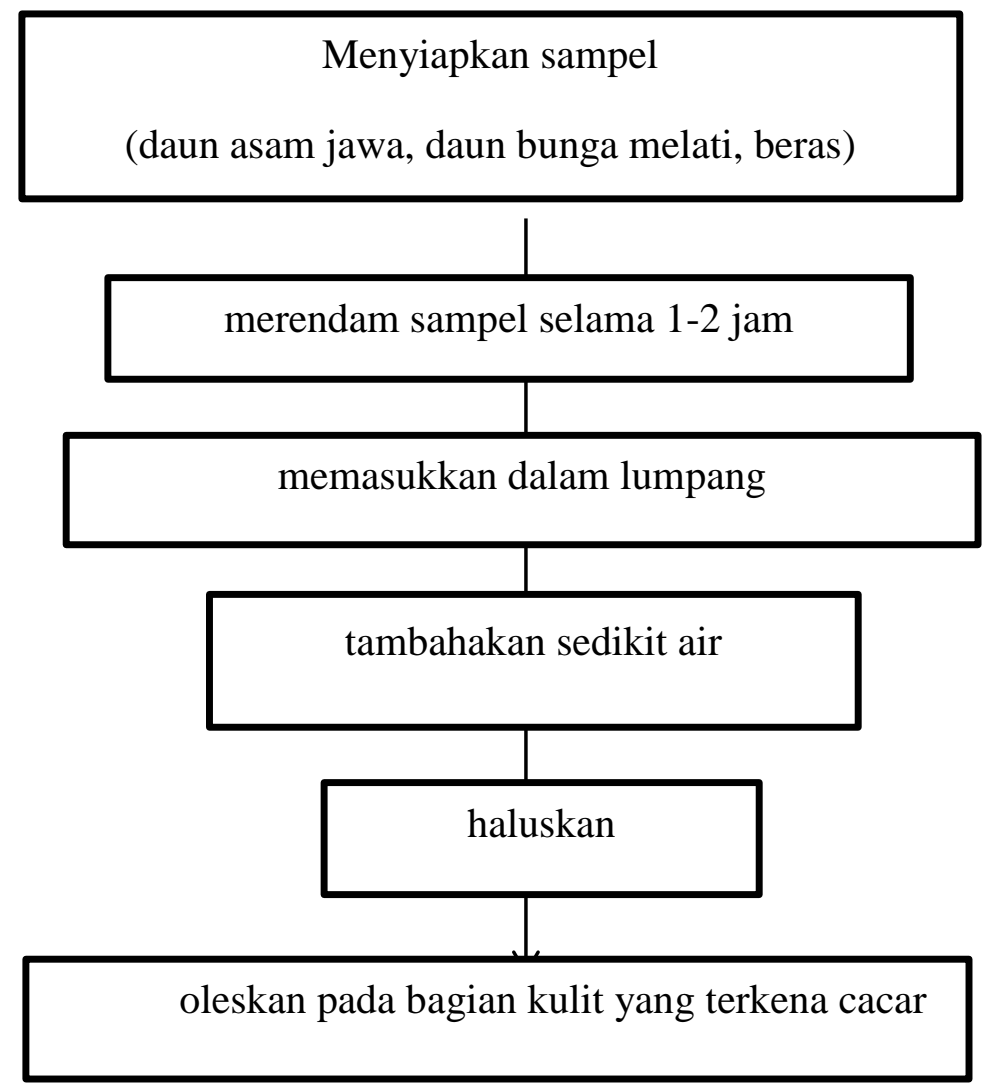

\section{HASIL}

1. Pembuatan ekstrak

Untuk membuat masker atau ekstrak daun asam jawa pertama ambil sekitar 1 genggam daun asam jawa, daun melati dan beras. Lalu cuci dan rendam bahan tersebut selama 1-2 jam. Setelah itu bahan di haluskan. Untuk pemakaian di oleskan pada bgaian kulit yang terkena cacar. Pemakaian biasanya 2x sehari

2. Pengujian dilakukan terhadap daun asam jawa dapat mengurasi penyakit cacar 


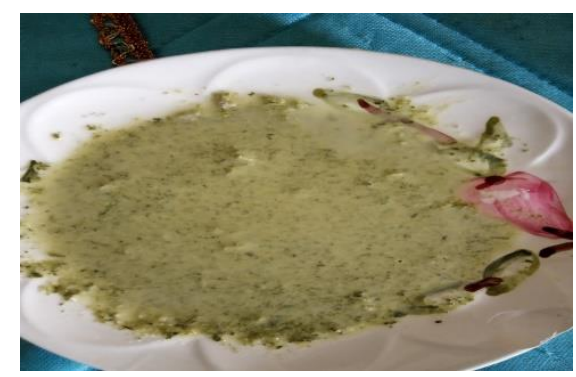

hasil

Tabel 1. Pengurangan ruam penyakit cacar pada kulit

\begin{tabular}{|l|l|l|l|}
\hline No. & Hari & $\begin{array}{l}\text { Variasi } \\
\text { daun }\end{array}$ & $\begin{array}{l}\text { Pengurangan } \\
\text { ruam }\end{array}$ \\
\hline 1 & $1-3$ & 1 genggam & 1 \\
\hline 2 & 4 & 2 genggam & 4 \\
\hline 3 & $5-7$ & 3 genggam & 5 \\
\hline 4 & 8 & 3 genggam & 7 \\
\hline 5 & 9 & 3 genggam & 9 \\
\hline 6 & 10 & 4 genggam & 12 \\
\hline
\end{tabular}




\section{PEMBAHASAN}

Pada eksperimen yang dilakukan pada daun asam jawa yang bertujuan untuk menyembuhkan penyakit cacar.

Tumbuhan asam jawa (Tamarindus indica L.) merupakan salah satu tumbuhan yang bnyak digunakan sebagai bahan pengobatan tradisonal. Bagian tumbuhan asam jawa yang biasa digunakan untuk pengobatan antara lain bagaian daun, kulit batang, daging buah, dan juga bijinya.[71-80]

Tamarindus indica L. Merupakan tumbuhan multiguna karena seluruh bagaian tumbuhan dapat dimanfaatkan dan dapat digunakan untuk mengobati berbagai macam penyakit seperti demam, disentri, hepatitis, gangguan pencernaan, dan cacar. [58-67]

Daun tanaman asam jawa memiliki bnayak kandungan zat aktif yang berkhsiat untuk menyembuhkan berbagai macam penyakit dan juga dapat menghambat pertumbuhan bakteri.[81-89]. Daun asam jawa juga memiliki kemampuan antibakteri, antijamur, dan aktivitas antioksidan.[68-71] Daun asam jawa memiliki banyak kandungan seperti protein, lemak, serat, asam tatrat, dan metabolit sekunder seperti alkaloid, saponin, tanin, falvonoid, dan mineral. Daun asam jawa juga mengandung vitamin seperti vitamin B1, vitamin B2, vitamin A, vitamin C, dan vitamin B kompleks. Esktrak daun asam jawa memiliki kandungan senyawa aktif berupa tanin, flavonoid dan saponin yang berkhasiat sebagai anti bakteri[90102]

Tanaman asam jawa ( Tamararindus indica L.) merupakan salah satu tanaman yang dapat mengurangi penyakit cacar. Pembuatan obat dari daun tanaman asam jawa ini juga tidak sulit, dan tidak perlu terlalu banyak menggunakan banyak biaya. Untuk membuat masker daun asam jawa cukup mengambil 16 genggam sampel daun asam jawa untuk 10 hari pemakaian. Untuk hari pertama sampai hari ketiga cukup menggunakan 1 genggam sampel. Untuk hari ke empat menggunakan 2 genggam sampel. Untuk hari kelima sampai hari kesembilan menggunakan 3 genggam sampel. Untuk hari ke sepuluh menggunakan 4 genggam sampel. Untuk percobaan kali ini jumlah cacar berkurang dengan tidak signifikan ini mungkin tergantung pemakai dan ketahanan tubuh pemakainya.[102-121]

Faktor yang mempengaruhi kemampuan ekstrak daun asam jawa sehingga menghambat pertumbuhan bakteri karena mengandung zat aktif saponin, flavonoid, alkaloid 
dan tanin. Daun asam jawa mengandung senyawa alkaloid yang mempunyai aktifitas sebagai antibakteri. Pada hari pertama menunjukkan pertumbuhan penyakit cacar berkurang. Peningkatan jumlah bakteri yang berkurang pada penyakit cacar pada hari ke-4 dan seterusnya.[122-140]

Pada percobaan kali ini digunkaan daun asam jawa untuk pengujian terhadap penyakit cacar. Dengan cara menempelkan hasil tumbukan daun asam jawa yang dita mbahkan daun bunga melati dan beras yang dihaluskan. Bahan tersebut ditempelkan pada kulit yang terkena cacar. Pada eksperimen ini didapat hasil.[141-150].
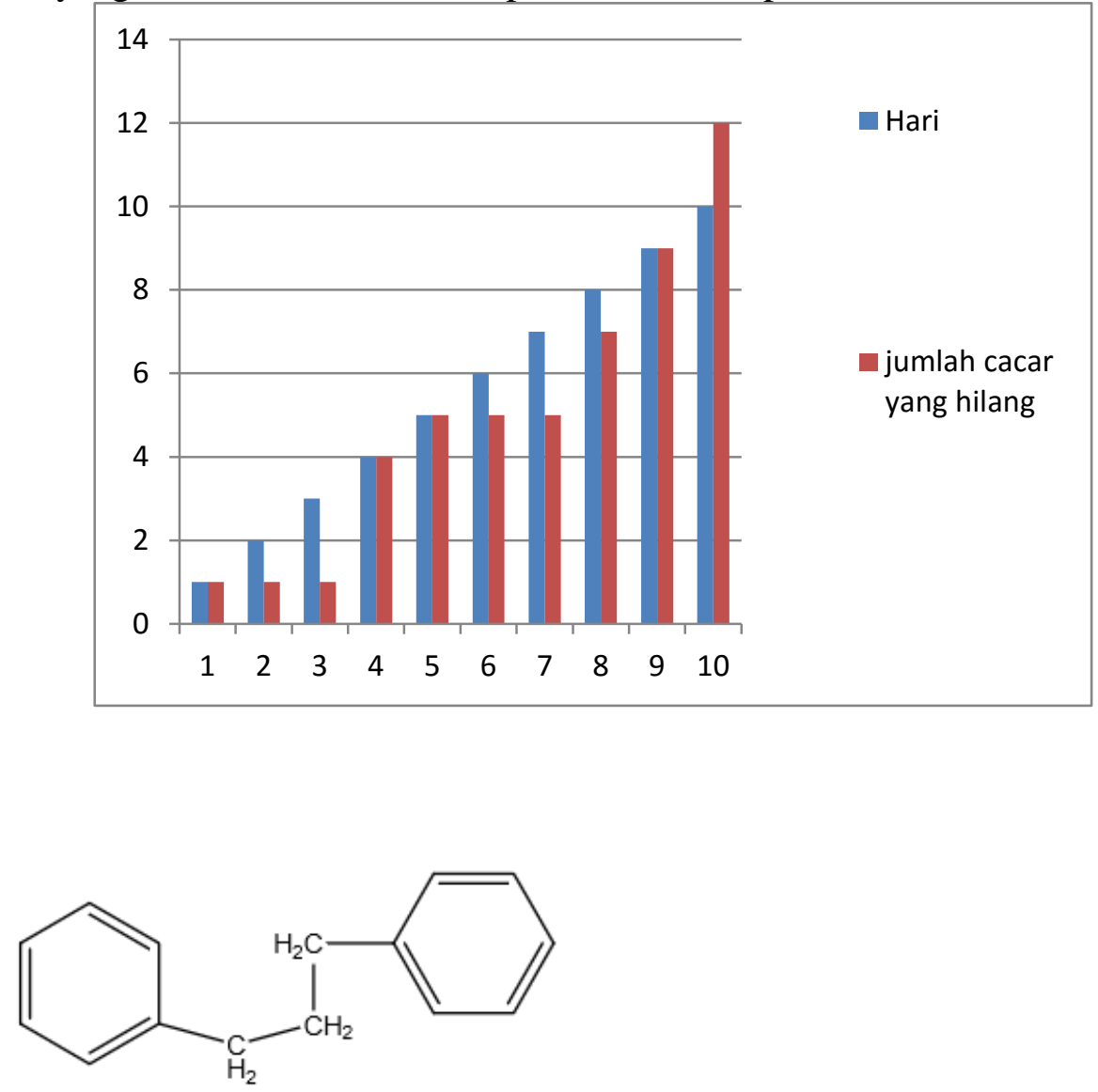

Gambar.Flavonoid

Sumber Google 


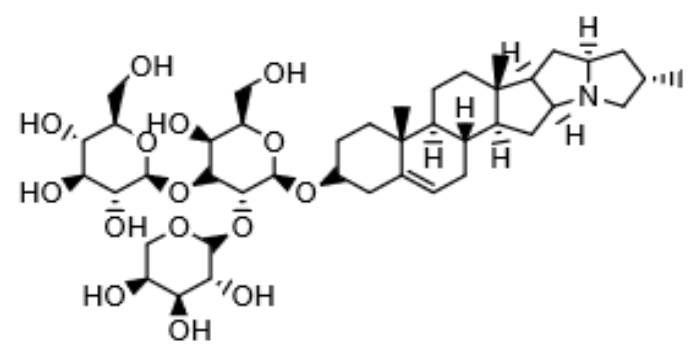

Gambar. Saponin

Sumber Google

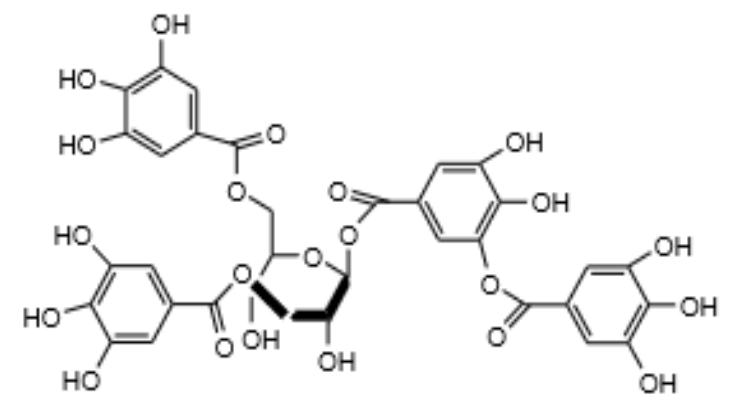

Gambar. Tannin

Sumber Google

\section{KESIMPULAN}

1. Ekstrak bisa dibuat dengan cara merendam dan penumbukan dari daun asam jawa

2. Ekstrak dapat menyembuhkan penyakit cacar

3. Kandungan yang terdapat didalam asam jawa yaitu zat aktif saponin, flavonoid, alkaloid, dan tanin. 


\section{REFERENSI}

[1] Rahmat Jaya, Eka Syahputra,Tri Utami.2015.Pemanfaatan Limbah Pecahan Genteng Sebagai Katalis Dalam Reaksi Pirolisis Plastik Polipropilena Menjadi Bahan Bakar. Jurnal Rekayasa Kimia Dan Lingkungan Vol. 10 , No. 3

[2] Sofyanita S, Octaria Z,. (2018). "Fenthion Compound Degradation In The Pesticide Bayleton 500 Ec In Sonolysis, Ozonolysis And Sonozolysis With Addition Of Tio2-Anatase", Eksakta: Berkala Ilmiah Bidang Mipa, 19(2), Pp 70-79. Doi 10.24036/Eksakta/Vol19Iss $2 / 153$

[3] Setianto S.(2017)."Analisa Kuantitatif Campuran Senyawa Oksida Sebagai Dasar Identifikasi Kandungan Bahan Sumber Daya Alam Studi Kasus: Kandungan Mineral Pada Pasir Besi Di Pesisir Pantai Selatan, Jawa Barat”. Eksakta: Berkala Ilmiah Bidang Mipa, 18(02), Pp 173-177. Doi: 10.24036/Eksakta/Vol18-Iss02/74

[4] Syafei N, Hidayat D, Emilliano E, Men L. (2018). “Analysis Cracking Corrosion On Carbon Steel Pipes Api 51-X65 In Solution 7700 Ml Aquades, 250 Ml Acetic Acid And 50 Ml Ammonia With Gas Co2 And H2s In Saturation Condition" Eksakta: Berkala Ilmiah Bidang Mipa, 19(2), Pp 21. Doi 10.24036/Eksakta/Vol19-Iss2/138

[5] Zainul, R. (2018, August 16). Effect Of Temperature And Particle Motion Against The Ability Of Zno Semiconductor Photocatalyst In Humic Acid. Https://Doi.Org/10.31227/Osf.Io/Wnygb

[6] Zainul, R. (2018, August 16). Determination Of The Half-Life And The Quantum Yield Of Zno Semiconductor Photocatalyst In Humic Acid. Https://Doi.Org/10.31227/Osf.Io/E8a9x

[7] Chaidir, Z., Fadjria, N., A., \& Zainul, R. (2018, August 11). Isolation And Molecular Identification Of Freshwater Microalgae In Maninjau Lake West Sumatera.

Https://Doi.Org/10.31227/Osf.Io/Nbcuf

[8] Dinata, M. And Soehardi, F.(2018) "Factor Analysis Of Physics Chemistry Waters That Affects Damage Safety Cliff On The Outskirts Of River Siak", Eksakta : Berkala Ilmiah Bidang Mipa, 19(2), Pp.46-49. Doi: 10.24036/Eksakta/Vol19-Iss1/143

[9] Ruswandi, R. (2018) “Determination Of Fructose Content Resulted By Inulin Hydrolysis With Dns As Oxidizer”, Eksakta: Berkala Ilmiah Bidang Mipa, 19(1), Pp. 14-23. Doi: 10.24036/Eksakta/Vol19-Iss1/102.

[10] Parbuntari, H., Prestica, Y., Gunawan, R., Nurman, M. And Adella, F. (2018) "Preliminary Phytochemical Screening (Qualitative Analysis) Of Cacao Leaves (Theobroma Cacao L.)", Eksakta: Berkala Ilmiah Bidang Mipa, 19(2), Pp. 40-45. Doi: 10.24036/Eksakta/Vol19-Iss2/142. 
[11] Zainul, R. (2018, August 16). Design And Modification Of Copper Oxide Electrodes For Improving Conversion Coefficient Indoors Lights (Pv-Cell) Photocells. Https://Doi.Org/10.31227/Osf.Io/Pgn84

[12] Zainul, R., Alif, A., Aziz, H., Arief, S., \& S. (2018, August 16). Photoelectrosplitting Water Mechanism At Carbon Electrode Surface Using Indoor Lights. Https://Doi.Org/10.31227/Osf.Io/Vcxq8

[13] Chaidir, Z., Zainul, R., Nurakhbari, D., \& Salim, M. (2018, July 29). Optimization Of Spirulina Platensis Culture For Antioxidant Production. Https://Doi.Org/10.17605/Osf.Io/Fd6e4

[14] Mukaromah, Ana Hidayati, Irawan, Bagus,2008. Pemanfaatan Reaktor Membran. Vol 1 , No 1

[15] Fotokatalitik Dalam Mendegradasi Fenol Dengan Katalisis Tio2 Dengan Adanya Ion Logam Fe(Iii) Dan Cu(Ii). Vol 1, No 1

[16] Rizqa, Ifan.2010. Perangkat Lunak Penyusunan Formula Herbal Sebagai Media Pelestarian Budaya Pengobatan Tradisional Khas Indonesia Vol 1, No 1

[17] Widodo, Winarso D., Kurniawati, Ani, P, Edi Djauhari. 2008. Motode Adaptasi Tanaman Sambung Nyawa Terhadap Cahaya-Uv Untuk Meningkatkan Produksi Flavonoid. Jurnal Ilmu Pertanian Indonesia. Vol 13, No 3

[18] Maryanto, Luthfi Eka, Basyirun, Basyirun, Anis, Samsudin.2018. Pengaruh Diameter Roller Terhadap Debit Pompa Peristaltik. Sainteknol. Vol.16 No.1

[19] Erawati Dewi, Luh Joni. 2009. Pengembangan Media Pembelajaran Reaksi Kesetimbangan Kimia. Jptk. Vol 6, No 2 (2009): Edisi Juli 2009

[20] Altway, Ali, Winardi, Sugeng, Rachimoellah, M,2004.Aplikasi Packet Diffusion Model Untuk Menganalisis Pengaruh Fenomena Micromixing Terhadap Jalannya Reaksi Kimia Paralel Di Dalam Reaktor Tangki Reraduk Kontinyu Dengan Aliran Umpan Terpisah. Vol 28, No 2

[21] Nunung D. Putra, Khaswar Syamsu, Ani Suryani,2004. Kajian Pengaruh Konsentrasi H2so4 Dan Suhu Reaksi Pada Proses Produksi Surfaktan Metil Ester Sulfonat (Mes) Dengan Metode Sulfonasi.Vol 14,No 2

[22] Irawan, Rm. Bagus,2006. Pengaruh Katalis Tembaga Dan Krom Terhadap Emisi Gas Carbon Monoksida Dan Hidro Carbon Pada Kendaraan Motor Bensin.Vol 4,No 1

[23] Kusnaryo, Radya Purna Wijaya, Ali Altway,. 2008. Analisa Transfer Massa Disertai Reaksi Kimia Pada Absorpsi Co2. Teknik Kimia. Vol 2, No 2 
[24] Diniatik, Soemardy, Eddy, Indri, Khanina. 2007. Perbandingan Kadar Flavonoid Total Dan Tanin Total Pada Teh Hijau Dan Teh Hitam Camellia Siniensis (L.) O.K. Pharmacy. Vol 5, No 3

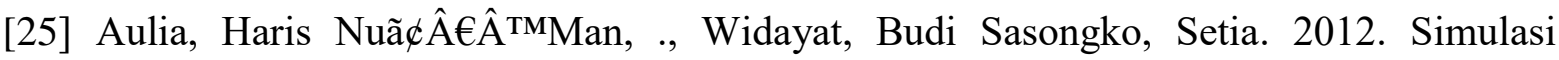
Kinetika Reaksi Transesterifikasi Minyak Goreng Bekas Berbantukan Radiasi Ultrasonik. Prosiding Seminar Nasional Sains Dan Teknologi Fakultas Teknik. Vol 1, No 1

[26] Rahmadhanty, S., \& Zainul, R. (2018, December 24). Design Of Humat Acid Solid Solution Reactor Through Phototransformation Of Copper Oxide (Cuo) Semiconductor Plate. Https://Doi.Org/10.31227/Osf.Io/Yhd9x

[27] Hary Sanjaya.(2017). "Degradasi Methylene Blue Menggunakan Katalis Zno-Peg Dengan Metode Fotosonolisis", Eksakta : Berkala Ilmiah Bidang Mipa,18(02), Pp.21-29. Doi:: 10.24036/Eksakta/Vol18-Iss02/45

[28] Vauzia, V. And Gusmira, E. (2018) "The Response Of Jabon Seeds Germination (Anthocephalus Cadamba (Roxb.)Miq.) Against The Duration Of Combustion And Illumination", Eksakta: Berkala Ilmiah Bidang Mipa, 19(2), Pp. 80-87. Doi:

10.24036/Eksakta/Vol19-Iss2/154.

[29] Joebaedi, K., Susanti, D., Warwah, N., Parmikanti, K. And Badrulfalah, B. (2019) "Factors Affecting The Amount Of Investment Loans In Commercial Banks With The Application Of Linear Regression Analysis Methods", Eksakta: Berkala Ilmiah Bidang Mipa, 20(1), Pp. 48-54. Doi: 10.24036/Eksakta/Vol20-Iss1/172.

[30] Pasaribu, F., Mardia, A. And Sormin, C. (2019) "Ordinal Logistic Regression With An Application To Health Service Quality In Raden Mattaher Jambi Hospital”, Eksakta: Berkala Ilmiah Bidang Mipa, 20(1), Pp. 35-40. Doi: 10.24036/Eksakta/Vol20-Iss1/168.

[31] Handayani, D. (2017) "Karakteristik Cendawan Dark Septate Endophyte (Dse) Pada Akar Tanaman Jagung Dan Padi”, Eksakta: Berkala Ilmiah Bidang Mipa, 18(01), Pp. 61-68. Doi: 10.24036/Eksakta/Vol18-Iss01/20.

[32] Ramli, R., Jonuarti, R. And Hartono, A. (2017) "Analisis Struktur Nano Dari Lapisan Tipis Cobalt Ferrite Yang Dipreparasi Dengan Metode Sputtering”, Eksakta: Berkala Ilmiah Bidang Mipa, 18(01), Pp. 46-53. Doi: 10.24036/Eksakta/Vol18-Iss01/16.

[33] Dwiky Prabowo, Eddy Afrianto, Iis Rostini.2017.Efektivitas Ekstrak Daun Asam Jawa Terhadap Masa Simpan Filet Nila Pada Suhu Rendah. Jurnal Perikanan Dan Kelautan Vol. Viii No. 2

[34] Mochamad Ma'roef, Arifatul Jannah. 2015.Pengaruh Pemberian Ekstrak Buah Asam Jawa (Tamarindus Indica) Terhadap Penurunan Kontraksi Otot Polos Uterus Terpisah Marmut Betina (Cavia Porcellus). Jurnal Ilmiah Kedokteran Universitas Muhammadiyah Malang Sumbersari Malang. Volume 11 No 2 D 
[35] Ruthia Kristi Wijayanti, Widya Dwi Rukmi Putri, Nur Ida Panca Nugrahini. 2016 . Pengaruh Proporsi Kunyit (Curcuma Longa L.) Dan Asam Jawa (Tamarindus Indica L) Terhadap Karakteristik Leather Kunyit Asam. Jurnal Pangan Dan Agroindustri Vol. 4 No 1

[36] Anggi Faradiba, Achmad Gunadi,Depi Praharan.2016. Daya Antibakteri Infusa Daun Asam Jawa (Tamarindus Indica Linn) Terhadap Streptococcus Mutans Antibacterial Activity Of Asam Jawa Leaf Infuse (Tamarindus Indica Linn) Against Streptococcus Mutans. E-Jurnal Pustaka Kesehatan, Vol 4(No. 1). Hal 56

[37] Tasim, Lina, Santoso, I R. S., Rombang, W A. R..2013.Analisis Pemahaman Konsep Reaksi Kimia Melalui Pendekatan Pembelajaran Langsung Pada Siswa Smp Negeri 13 Tidore Kepulauan Vol 1, No 3

[38] Sukardi, Sukardi.2001.Antioksidan Alami Sebagai Pengawet Makanan Dan Pemeliharaan Kesehatan Tubuh Vol 2no 31

[39] Dwi Wijayanti, Agustina , Fumia Maria, Alian, Nur Khasanah, Siti.2011.Pengaruh Pemberian Ekstrak Kunyit Putih (Curcuna Alba) Terhadap Nilai Hb (Hemoglobin), Pcy (Packed Cell Volume), Jumlah Dan Diferensial Lekosit Tikus Yang Terpapar Asap Sepeda Motor. Jurnal Sain Veteriner.Vol 1, No 29

[40] Hermawanti,Laily.2015.Penggabungan Algoritma Backward Eliminationdannaive Bayes Untuk Mendiagnosis Penyakit Kanker Payudara. Momentum.Vol 11, No 1

[41] Sari Safitri, Tika Yolanda, Visca Alisia, Rahadian Zainul.(2018, Oktober 12). Solid Stated: Priciples And Methode . Https://Doi.Org/10.1227/Osf.Io/7us4x

[42] Yulis, R., Zainul, R., \& M. (2018, December 10). Desain Dan Karakterisasi Sel Surya Sistem Elektroda Tembaga (I) Oksida (Cu2o/Al) Model Pipa Pada Larutan Natrium Sulfat (Na2so4). Https://Doi.Org/10.31227/Osf.Io/M43js

[43] Zainul, R. (2018, October 12). A Review Grinding : Teknik Dan Prinsip Dasar Pada Pengolahan Material. Https://Doi.Org/10.31227/Osf.Io/Trv4q

[44] Putri, D., Fifendy, M. And Putri, M. (2018) "Diversitas Bakteri Endofit Pada Daun Muda Dan Tua Tumbuhan Andaleh (Morus Macroura Miq.)", Eksakta: Berkala Ilmiah Bidang Mipa, 19(1), Pp. 125-130. Doi: 10.24036/Eksakta/Vol19-Iss1/122.

[45] Sari A. (2017). "Potensi Antioksidan Alami Pada Ekstrak Daun Jamblang (Syzigium Cumini L)" Eksakta: Berkala Ilmiah Bidang Mipa, 18(02), Pp.107-112. Doi: 10.24036/Eksakta/Vol18-Iss02/61

[46] Nurfadilah, K. K., \& Zainul, R. (2019, February 3). Kalium Nitrat (Kno3): Karakteristik Senyawa Dan Transpor Ion. Https://Doi.Org/10.31227/Osf.Io/Dr8ef

[47] Kristy, D. P., \& Zainul, R. (2019, February 3). Analisis Molekular Dan Transpor Ion Natrium Silikat. Https://Doi.Org/10.31227/Osf.Io/8ac4m 
[48] Y., \& Zainul, R. (2018, November 18). Silver Sulfate (Ag2so4): Molecular Analysis And Ion Transport. Https://Doi.Org/10.31227/Osf.Io/N8g9k

[49] Husna, A. D., \& Zainul, R. (2019, February 4). Analisis Molekular Dan Karakteristik Hidrogen Sianida (Hcn). Https://Doi.Org/10.31227/Osf.Io/7xej9

[50] Tuti Tutuarima.(2017)."Sifat Fisik Dan Sifat Kimia Marmalade Jeruk Kalamansi (Citrus Microcarpa): Kajian Kosentrasi Pektin Dan Sukrosa", Eksakta: Berkala Ilmiah Bidang Mipa, 18(02), Pp 164-172. Doi/10.24036/Eksakta/Vol18-Iss02/73

[51] Syafei, Nendi Suhendi.(2017). "Analisa Fenomena Korosi Pelat Pipa Baja Karbon Api 51-X65 Dalam Larutan 250 Ml Asam Aseta Dan 4750 Ml Aquades Pada Kondisi Gas Co2 Dan H2s Jenuh Pada Suhu Ruang”, Eksakta: Berkala Ilmiah Bidang Mipa,18(02) Pp,113-120. Doi: 10.24036/Eksakta/Vol18-Iss02/63

[52] Winata, Susanty D .2003. Cara Bijak Menggunakan Obat Herbal Vol. 11 No. 29

[53] Uddin, Baha. 2006. Dari Mantri Hingga Dokter Jawa:Studi Kebijakan Pemerintah Kolonial Dalam Penanganan Penyakit Cacar Di Jawa Abad Xix - Xx.Jurnal Humaniora. Volume 18 No. 3

[54] Faustina, Prapto Yudono, Dan Rohmanti Rabaniyah, Ega .2012. Pengaruh Cara Pelepasan Aril Dan Konsentrasi Kno3 Terhadap Pematahan Dormansi Benih Pepaya (Carica pPapaya L.) Vol 1, No 1

[55] Muliani, Hirawati .2010.Struktur Mikroanatomi Ren Ayam (Gallus Sp.) Karena Pengaruh Pemberian Kunyit Putih (Curcuma Zedoaria). Jurnal Anatomi Fisiologi. Vol 18, No 2

[56] Charlena, Purwaningsih,Henny, Rosdiana,Tina. 2008. Pencirian Dan Uji Aktivitas Katalitik Zeolit Alam Teraktivasi. Jurnal Riset Kimia. Vol 1, No 2.

[57] Malangngi, Liberty , Sangi, Meiske, Paendong, Jessy . 2012. Penentuan Kandungan Tanin Dan Uji Aktivitas Antioksidan Ekstrak Biji Buah Alpukat (Persea Americana Mill.). Jurnal Mipa Unsrat Onlin. Vol 1, No 1.

[58] Darminto, . ( State University Of Makassar ), Muharram, .. 2009. Senyawa Alkoloid Dari Ekstrak Aseton Daun Sambung Nyawa Gynura Procumbens L. (Gpl). Bionature. Vol 10 , No 1

[59] Megawati, Megawati , Sediawan, Wahyudi Budi,Sulistyo, Hary,Hidayat, Muslikhin.2009.Kinetika Reaksi Hidrolisis. Reaktor. Vol.12 No.4

[60] Febriani, S. S., Yolanda, T., Arianti, V. A., \& Zainul, R. (2018, October 12). A Review Solid Stated : Principles And Methode. Https://Doi.Org/10.31227/Osf.Io/7us4x 
[61] Lubis, A. P., \& Zainul, R. (2018, November 5). Interaksi Molekuler Amonium Hidroksida. Https://Doi.Org/10.31227/Osf.Io/Jht3

[62] Liza, Y. M., Yasin, R. C., Maidani, S. S., \& Zainul, R. (2018, October 9). Sol Gel : Principle And Technique (A Review). Https://Doi.Org/10.31227/Osf.Io/2cuh8

[63] Kusumawardhani, Amalia, Widodo, Winarso Drajad.2003. Pemanfaatan Pupuk Majemuk Sebagai Sumber Hara Budidaya Tomat Secara Hidroponik. Jurnal Agronomi Indonesia. Vol.31 No.1

[64] Iswari, K.2015. Pemanfaatan Tomat Dan Sirsak Sebagai Bahan Dasar Pembuatan Produk Suplemen Kesehatan. Jurnal Holtikultura. Vol.25 No.4

[65] Dinata, A. A., Rosyadi, A. M., Hamid, S., \& Zainul, R. (2018, October 15). A Review Chemical Vapor Deposition : Process And Application. Https://Doi.Org/10.31227/Osf.Io/Yfeau

[66] Alfionita, T., \& Zainul, R. (2019, January 29). Calcium Chloride (Cacl2) : Characteristics And Molecular Interaction In Solution.

Https://Doi.Org/10.31227/Osf.Io/M37xj

[67] Susanti, N. M. P., Dewi, L. P. M. K., Widjaja, I N.K., Wirasuta, I.M.A.G., Gityarani, K. G.2016. Ekstraksi Likopen Dari Limbah Buah Tomat (Solanumlycopersicum L.). Jurnal Farmasi Udayana. Vol.5 No.1.

[68] Sari, Diana Permata , Purwarianti, Ayu.2014. Ekstraksi Kata Kunci Otomatis Untuk Dokumen Bahasa Indonesia Studi Kasus: Artikel Jurnal Ilmiah Koleksi Pdii Lipi. Jurnal Dokumentasi Dan Informatika.Vol.35 No.2

[69] Zainul, R., \& Prima, C. B. (2018, November 11). Desain Geometri Sel Pv. Https://Doi.Org/10.31227/Osf.Io/7n8t4

[70] Artika, P. I., \& Zainul, R. (2018, November 19). Potassium Bromide (Kbr): Transformasi Ionik Dan Sifat Temodinamika Dalam Larutan. Https://Doi.Org/10.31227/Osf.Io/A5hyz

[71] Shafitri, M., \& Zainul, R. (2019, February 3). Vanadium Pentaoksida (V2o5) :

Termodinamika Molecular Dan Interaksi Ion Dalam Larutan.

Https://Doi.Org/10.31227/Osf.Io/Jgmvd

[72] Yanti, C. F., \& Zainul, R. (2018, December 2). A Review Ba (Oh)2 : Transpor Ionik Pada Barium Hidroksida Di Dalam Air Dengan Konsep Termodinamika.

Https://Doi.Org/10.31227/Osf.Io/Fsbq3

[73] Al Hakimi, Nurush Shofi, Hanapi, Ahmand, Fasya, Ahmad Ghanaim,2017.Green Synthesis Senyawa Imina Dari Vanillin And Anilina Dengan Katalis Alami Air Jeruk Nipis (Citrus Aurantifolia). Vol 5, No 4 
[74] Soemardi, Eddy, Utami, Pri Iswati, Wakhid, Abdul,2003. Uji Anti Bakteri Ekstrak Air Kunyit (Curcuma Domestica, Val.) Terhadap Bakteri Pseudomonas Aeruginosa Pada Ikan Gurami (Osphronemus Gouramy. Lac). Vol 1, No 1

[75] Wardhani, Ratih Pramita, Ningsih, Rini Rahayu, Ramadhona, Rika, Astuti, Hutari Puji,Fitriyani, Noor,2013. Teh Biji Semangka (Citrullus Lanatus) Sebagai Obat Herbal Alternatif Jantung Dan Anti Kanker. Vol. 4, No.2

[76] Chifdhiyah, Alina Nuru.2012.Pengaruh Penambahan Ekstrak Kunyit Putih (Kaempferia Rotunda) Terhadap Jumlah Total Hemosit Dan Aktifitas Fagositosis Udang Windu (Penaeus Monodon) Journal Of Aquaculture Management And Technology. Vol 1, No 1

[77] Husna, H., \& Zainul, R. (2019, February 3). A Review : Aspek Termodinamika Lino3 Dalam Larutannya. Https://Doi.Org/10.31227/Osf.Io/45mbd

[78] Delvi, I. P., \& Zainul, R. (2019, February 3). Mercury (Ii) Nitrate (Hg (No3)2): Interaksi Molekul Dan Adsorpsi Hg Dengan Karbon Aktif. Https://Doi.Org/10.31227/Osf.Io/Eqyax

[79] Iryani, I., Iswendi, I. And Katrina, I. T. (2017) "Uji Aktivitas Anti Diabetes Mellitus Senyawa Metabolit Sekunder Fraksi Air Dari Beras Ketan Hitam ( Oryza Satival. Var Glutinosa) Pada Mencit Putih", Eksakta: Berkala Ilmiah Bidang Mipa, 18(01), Pp. 54-60. Doi: 10.24036/Eksakta/Vol18-Iss01/17.

[80] Rizki Saputra, M. And Sumarmin, R. (2018) "Pengaruh Ekstrak Daun Sirih Merah (Piper Crocatum Ruiz \& Pav.) Terhadap Glukosa Darah Mencit (Mus Musculus L.) Jantan Yang Diinduksi Sukrosa", Eksakta: Berkala Ilmiah Bidang Mipa, 19(1), Pp. 43-55. Doi: 10.24036/Eksakta/Vol19-Iss1/124.

[81] Ningsih Sk.(2017)."'Sintesis Dan Karakterisasi Nanopartikel Zno Doped Cu2+ Melalui Metoda Sol Gel", Eksakta:Berkala Bidang Ilmiah Mipa, 18(02), Pp39-41. Doi:10.24036/Eksakta/Vol18-Iss02/51

[82] Mulia M. (2017). "Isolasi Kumarin Dari Kulit Buah Limau Sundai (Citrus Nobilis Lour)", Eksakta: Berkala Ilmiah Bidang Mipa,18(02) Pp.137-45. Doi: 10.24036/Eksakta/Vol18-Iss02/70

[83] Warlinda, Y. A., \& Zainul, R. (2019, January 29). Asam Posfat (H3po4): Ionic Transformation Of Phosphoric Acid In Aqueous Solution. Https://Doi.Org/10.31227/Osf.Io/S3y8v

[84] Sari, E. S. J., \& Zainul, R. (2019, January 31). Nitrogen Triflorida (Nf3) : Termodinamika Dan Transpor Elektron Nf3. Https://Doi.Org/10.31227/Osf.Io/3nzrh [85] Sumarmin, R. (2018) 'Pengaruh Ekstrak Kulit Buah Manggis (Garcinia Mangostana L.) Terhadap Histologis Pankreas Mencit (Mus Musculus L. Swiss Webster) Yang Diinduksi Sukrosa", Eksakta: Berkala Ilmiah Bidang Mipa, 19(1), Pp. 100-112. Doi: 10.24036/Eksakta/Vol19-Iss1/123. 
[86] Rizki Saputra, M. And Sumarmin, R. (2018) "Pengaruh Ekstrak Daun Sirih Merah (Piper Crocatum Ruiz \& Pav.) Terhadap Glukosa Darah Mencit (Mus Musculus L.) Jantan Yang Diinduksi Sukrosa", Eksakta: Berkala Ilmiah Bidang Mipa, 19(1), Pp. 43-55. Doi: 10.24036/Eksakta/Vol19-Iss1/124.

[87] Sari, A. (2017) "Potensi Antioksidan Alami Pada Ekstrak Daun Jamblang (Syzigium Cumini (L.) Skeels)”, Eksakta: Berkala Ilmiah Bidang Mipa, 18(02), Pp. 107-112. Doi: 10.24036/Eksakta/Vol18-Iss02/61.

[88] Amananti, W. (2017) “Analisis Mikrostruktur Lapisan Tipis Tio2:Zno Yang Dideposisikan Diatas Subtrat Kaca Dengan Metode Spray Coating Untuk Degradasi Limbah Zat Warna", Eksakta: Berkala Ilmiah Bidang Mipa, 18(02), Pp. 210-215. Doi: 10.24036/Eksakta/Vol18-Iss02/81

[89] Putri, D., Fifendy, M. And Putri, M. (2018) "Diversitas Bakteri Endofit Pada Daun Muda Dan Tua Tumbuhan Andaleh (Morus Macroura Miq)", Eksakta: Berkala Ilmiah Bidang Mipa, 19(1), Pp. 125-130. Doi: 10.24036/Eksakta/Vol19-Iss/122

[90] Hidayani, T. (2018) "Grafting Polipropilena Dengan Maleat Anhidrida Sebagai Pengikat Silang Dengan Inisiator Benzoil Peroksida”, Eksakta: Berkala Ilmiah Bidang Mipa, 19(1), Pp. 56-62. Doi: 10.24036/Eksakta/Vol19-Iss1/127.

[91] Zainul, R. And Wardani, S. (2019) "The Hydrogen Generator Performance Of Sandwich Designed 4/4 Al-Cu Plates", Eksakta: Berkala Ilmiah Bidang Mipa, 20(1), Pp. 100-104. Doi: 10.24036/Eksakta/Vol20-Iss1/177.

[92] Dwynda, I., \& Zainul, R. (2018, November 19). Boric Acid (H3 (Bo3): Recognize The Molecular Interactions In Solutions. Https://Doi.Org/10.31227/Osf.Io/6wead

[93] Putri, G. E., Arief, S., Jamarun, N., Gusti, F. R., \& Zainul, R. (2018, December 10). Microstuctural Analysis And Optical Properties Of Nanocrystalline Cerium Oxides Synthesized By Precipitation Method. Https://Doi.Org/10.31227/Osf.Io/Qcz4y

[94] Sari, M., \& Zainul, R. (2018, November 19). Kalium Dikromat (K2cr2o7) Spektroskopi Dan Transpor K2cr2o7. Https://Doi.Org/10.31227/Osf.Io/W92je

[95] Horiza, H., Azhar, M. And Efendi, J. (2017) "Ekstraksi Dan Karakterisasi Inulin Dari Umbi Dahlia (Dahlia Sp.L) Segar Dan Disimpan”, Eksakta: Berkala Ilmiah Bidang Mipa, 18(01), Pp. 31-39. Doi: 10.24036/Eksakta/Vol18-Iss01/14.

[96] Samah, S. (2017) "Karakterisasi Plastik Biodegradabel Dari Ldpe-G-Ma Dan Pati Tandan Kosong Sawit", Eksakta: Berkala Ilmiah Bidang Mipa, 18(02), Pp. 30-38. Doi: 10.24036/Eksakta/Vol18-Iss02/48.

[97] Chatri, M., Mansyurdin, M., Bakhtiar, A. And Adnadi, P. (2017) "Perbandingan Komponen Minyak Atsiri Antara Daun Muda Dan Daun Dewasa Pada Hyptis Suaveolens (L.)Poit”, Eksakta: Berkala Ilmiah Bidang Mipa, 18(02), Pp. 1-12. Doi:

10.24036/Eksakta/Vol18-Iss02/41. 
[98] Dinata, M., Fitridawati, F. And Putri, L. (2019) "The Study Trees Potential For Forest In Universitas Lancang Kuning Pekanbaru”, Eksakta: Berkala Ilmiah Bidang Mipa, 20(1), Pp. 77-85. Doi: 10.24036/Eksakta/Vol20-Iss1/176.

[99] Fajri, Fifteen Aprilia.2009. Aktivasi Antidiare Ekstrak Etanol Daun Seledri ( Apium graveolens) Pada Mencit Jantan. Jurnal Ilmiah Farmasi Vol 6, No 1.

[100] Advinda, L. (2018) "Pertumbuhan Stek Horizontal Batang Jarak Pagar (Jatropha Curcas L.) Yang Diintroduksi Dengan Pseudomonad Fluoresen”, Eksakta: Berkala Ilmiah Bidang Mipa, 19(1), Pp. 68-75. Doi: 10.24036/Eksakta/Vol19-Iss1/129.

[101] Elisabeth, Jenny, Siahaan, D., Simajuntak, D. R. H. 2012. Pemanfaatan Bahan Tumbuhan Sebagai Biokatalisator Dalam Produksi Minyak Sawit Kaya Asam Lemak Omega-3 1) [Using Of Plant Biocatalisator For Omega-3 Pufa -Rich Palm Oil Production]. Jurnal Teknologi Dan Industri Pangan. Vol 13, No 2

[102] Kurniawati, Diani, Rukmi, Mg. Isworo, Lunggani, Arina Tri .2014 .Aktivitas Antimikroba Kombinasi Rebusan Daun Sirih Hijau (Piper Betle) Dan Daun Sirih Merah (Piper Crocatum) Terhadap Candida Albicans. Jurnal Biologi. Vol. 3 No.

[103] Hamidy, M Yulis, Malik, Zulkifli, Machyar, Ryan Mutiara. 2012. Gambaran Histopatologi Kerusakan Hati Mencit Yang Diproteksi Dengan Air Rebusan Daun Sirih (Piper Betle Linn). Jik (Jurnal Ilmu Kedokteran). Vol 3, No 1

[104] Harlis, Harlis, Wahyuni, Indah.2012. Pengaruh Ekstrak Daun Sirih (Piper Betle Linn.) Terhadap Pertumbuhan Bakteri Streptococcus Viridans. Biospecies. Vol 1, No 1

[105] Widodo, Prasetya, Agus. 2014. Modifikasi Sistem Destilasi Minyak Atsiri Daun Sirih (Piper Betle Linn) Dengan Penerapan Volume Air Rebusan Konstan. Asean Journal Of Systems Engineering. Vol 2, No 1

[106] Hakimi, A., \& Zainul, R. (2019, January 31). Asam Arsenat (H3aso4) : Analisis Molekular Dan Karakteristik Senyawa. Https://Doi.Org/10.31227/Osf.Io/E486z

[107] Arifulloh, Arifulloh, Oktavianawati, Ika, Adi Winata, I Nyoman.2016. Ekstraksi Likopen Dari Buah Tomat (Lycopersicum Esculentum Mill.) Dengan Berbagai Komposisi Pelarut. Berskala Sainstek. Vol.4 No.1

[108] Harahap, F. And Lubis, L. (2018) “Analysis Of Heavy Metals Distribution In The River Town Of Hamasaki's Rod Padangsidimpuan”, Eksakta: Berkala Ilmiah Bidang Mipa, 19(2), Pp. 50-56. Doi: 10.24036/Eksakta/Vol19-Iss2/149.

[109] Prihatini, R. (2017) "Pemanfaatan Air Kelapa Untuk Meningkatkan Pertumbuhan Akar Stek Tunas Aksilar Andrographis Paniculata Nees", Eksakta: Berkala Ilmiah Bidang Mipa, 18(02), Pp. 62-68. Doi: 10.24036/Eksakta/Vol18-Iss02/54.

[110] Santoso, B., Setianto, S., Hasanah, M., Wijatmoko, B., Supriyana, E. And Mohammad, H. (2018) "Mitigation Of Land Movement Using Self Potential Method In Ling-Anjung 
Region Sumedang Regency”, Eksakta: Berkala Ilmiah Bidang Mipa, 19(2), Pp. 32-39. Doi: 10.24036/Eksakta/Vol19-Iss2/141.

[111] Fati, N., Siregar, R. And Sujatmiko, S. (2019) “Addition Of Coleus Amboinicus, L Leaf's Extract In Ration To Percentage Of Carcass, Abdominal Fat, Liver And Heart Broiler", Eksakta: Berkala Ilmiah Bidang Mipa, 20(1), Pp. 1-9. Doi: 10.24036/Eksakta/Vol20-Iss1/157.

[112] Nasir, M. (2017) "Pengaruh Waktu High Energy Milling Terhadap Karakteristik Nanokaolin Capkala Asal Kalimantan Barat”, Eksakta: Berkala Ilmiah Bidang Mipa, 18(02), Pp. 200-209. Doi: 10.24036/Eksakta/Vol18-Iss02/78.

[113] Enjelina, W., Mansyurdin, M. And Meideliza, T. (2018) "Analysis Of Nepenthes Hybrids In Bukik Taratak West Sumatra By Rapd Technique", Eksakta: Berkala Ilmiah Bidang Mipa, 19(2), Pp. 12-20. Doi: 10.24036/Eksakta/Vol19-Iss2/137.

[114] Ramalisa, Y., Febriyanti, A. And Multahadah, C. (2019) “Analysis Of Non Hierarchical Bomb For Collection Of Community Health Degrees In Jambi And Muaro Jambi City”, Eksakta: Berkala Ilmiah Bidang Mipa, 20(1), Pp. 25-34. Doi: 10.24036/Eksakta/Vol20-Iss1/167.

[115] M., Sanjaya, H., \& Zainul, R. (2018, August 11). Characterization Of Napa Soil And Adsorption $\mathrm{Of} \mathrm{Pb}$ (Ii) From Aqueous Solutions Using On Column Method.Https://Doi.Org/10.31227/Osf.Io/T8fh9

[116] Nasution, A. W., Putri, R. N., Mayendra, E., \& Angraini, L. P. (2019, April 29). Mengkaji Karakteristik Pemakai Teknologi Pengolahan Air Bersih Di Indonesia. Https://Doi.Org/10.31227/Osf.Io/Bzqy7

[117] Yuliani, F., \& Zainul, R. (2018, November 13). Analisis Termodinamika Molekul Magnesium Sulphate (Mgso4). Https://Doi.Org/10.31227/Osf.Io/Uxz4y

[118] Jumalia, R., \& Zainul, R. (2019, February 3). Natrium Karbonat : Termodinamika Dan Transport Ion. Https://Doi.Org/10.31227/Osf.Io/Y2vq9

[119] Iskandar, I., Horiza, H. And Fauzi, N. (2017) “Efektivitas Bubuk Biji Pepaya (Carica Papaya Linnaeaus) Sebagai Larvasida Alami Terhadap Kematian Larva Aedes Aegypty Tahun 2015”, Eksakta: Berkala Ilmiah Bidang Mipa, 18(01), Pp. 12-18. Doi: 10.24036/Eksakta/Vol18-Iss01/12

[120] Joebaedi, K. (2018) "Model Star(1;1) Pada Data Produktivitas Teh", Eksakta: Berkala Ilmiah Bidang Mipa, 19(1), Pp. 35-38. Doi: 10.24036/Eksakta/Vol19-Iss1/118.

[121] Anggoro Didi Dwi Dan Budi Faleh Setia. 2008. Proses Gliserolisis Minyak Kelapa Sawit Menjadi Mono Dan Diacyl Gliserol Dengan Pelarut N-Butanol Dan Katalis Mgo. Jurnal Teknik Kimia Vol 12, No 1 
[122] Indraswary, Recita. 2011. Efek Konsentrasi Ekstrak Buah Adas (Foeniculum Vulgare Mill.) Topikal Pada Epitelisasi Penyembuhan Luka Gingiva Labial Tikus Sprague Dawley In Vivo. Jurnal Majalah Ilmiah Sultan Agung Vol 49, No 124

[123] Batubara, Irmanida, Abidin, Zaenal, Rahminiwati, Min. 2011. Ekstrak Secang Berukuran Nano Dengan Kaolin Sebagai Pembawa. Jurnal Ilmu Pertanian Indonesia Vol 16, No 2

[124] Lubis, Humairah Medina Liza. 2018. Kajian Molekuler P53 Pemanfaatan Tanaman Herbal Buah Legundi (Vitex Trifolia L) Terhadap Massa Tumor Jaringan Kulit. Buletin Farmatera. Vol 3, No 1 (2018)

[125] Suwondo, Syarif Sidik, Sumadilaga R, Soelarko R. M. . 2012. Aktivitas Antibakteri Daun Sirih (Piper Betle L.) Terhadap Bakteri Gingivitis Dan Bakteri Pembentuk Plak/Karies Gigi (Streptococcus Mutans). Warta Tumbuhan Obat Indonesia. Vol 1, No 1

[126] Feronika, N. I., \& Zainul, R. (2018, November 19). Kalium Permanganat: Termodinamika Mengenai Transport Ionik Dalam Air.

Https://Doi.Org/10.31227/Osf.Io/G6eyk

[127] Lasarus, Agnesi.2013. Uji Efek Analgesik Ekstrak Daun Pepaya (Carica Pepaya (L.)) Pada Mencit (Mus Musculus) Vol 1, No 2

[128] Utama Sri, Syaufina Lailan, Haneda Noor Farikhah. 2010. Daya Racun Ekstrak Kasar Daun Bintaro (Cerbera Odollam Gaertn.) Terhadap Larva Spodoptera Litura Fabricius. Jurnal Ilmu Pertanian Indonesia Vol 15, No 2

[129] Latief Madyawati, Soeardjo Supriyatna, Bhati Husein H., Dachriyanus. 2007. Kandungan Kimia Dari Fraksi Aktif Antioksidan Ekstrak Kulit Batang Garcinia fornesi King. Jurnal Farmasi Vol 5, No 1

[130] Irani, A. (2019, April 19). Studi Katalitik Herbal Tumbuhan Bandotan (Agerantum Conyzoides L.) Dalam Mempercepat Proses Penyembuhan Luka Luar.

Https://Doi.Org/10.31227/Osf.Io/Mfuae

[131] R Zainul, B Oktavia, I Dewata And J Efendi. (2018). Thermal And Surface Evaluation On The Process Of Forming A Cu2o/Cuo Semiconductor Photocatalyst On A Thin Copper Plate . Doi: Https://Iopscience.Iop.Org/Article/10.1088/1757-899x/335/1/012039/Meta

[132] Hadikusumo, Sutjipto A. 2007. Pengaruh Ekstrak Tembakau Terhadap Serangan Rayap Kayu Kering Cryptotermes Cynocephalus Light Pada Bambu Apus (Gigantochloa Apus Kurz). Jurnal Ilmu Kehutanan Vol 1, No 2

[133] Rahman, Erwid Fatchur. 2010. Efektivitas Ekstrak Daun Dewa (Gynura Pseudochina (Lour.). Terhadap Pertumbuhan Candida Albicans Pada Plat Dasar Gigi Tiruan Resin Akrilik. Jurnal Majalah Ilmiah Sultan Agung Vol 48, No 123 
[134] Ariyani Farida, Murtini Jovita Tri, Siregar Tuti. 2010. Penggunaan Ekstrak Daun Jambu Biji (Psidium guajava) Sebagai Pengawet Pindang Tongkol. Jurnal Pascapanen Dan Bioteknologi Kelautan Dan perikanan Vol 5, No 1.

[135] Goenarwo, Edijanti. 2011. Pengaruh Pemberian Ekstrak Angkak Terhadap Kadar Hdl Darah (Studi Eksperimental Pada Tikus Jantan Galur Wistar Yang Mendapat Diet Tinggi Lemak). Jurnal Majalah Ilmiah Sultan Agung Vol 49, No 125

[136] Suprijono , Sumarno , Kusuma, Lirans Tia. 2011. Engaruh Ekstrak Rimpang Curcuma Alba Terhadap Volume Adenokarsinoma Mamma. Jurnal Majalah Ilmiah Sultan Agung Vol 49, No 125

[137] Wardani, Ratih Sari, ., Mifbakhuddin, Yokorinanti, Kiky. 2010. Pengaruh Konsentrasi Ekstrak Daun Tembelekan (Lantana Canara) Terhadap Kematian Larva Aedes Egypti. The Indonesian Journal Of Public Health Vol 6, No 2

[138] Fikri, Muhammad Zakiyul, Nurhayati, Tati, Salamah, Ella. 2014. Ekstraksi Dan Karakterisasi Parsial Ekstrak Kasar Enzim Katepsin Dari Ikan Patin [Extraction And Partial Characterization Of Crude Enzymes Cathepsin From Catfish]. Jurnal Teknologi Dan Industri Pangan Vol 25, No 1

[139] Yeni, Yeni Dianita, Djannah, Sitti Nur, Nurani, Laela Hayu. 2010. Uji Aktivitas Antibakteri Infusa Daun Sirsak (Annona Muricata L.) Secara In Vitro Terhadap Staphylococcus Aureus Atcc 25923 Dan Escherichia Coli Atcc 35218 Serta Profil Kromatografi Lapis Tipisnya. Jurnal Kesehatan Masyarakat (Journal Of Public Health) Vol 4, No 3

[140] Sumardiyono Christanti , Hartono Sedyo , Nasrun Nasrun . 2013. Pengendalian Penyakit Budok Dengan Fungisida Dan Deteksi Residu Pada Daun Nilam. Jurnal Fitopatologi Indonesia Vol 9 , No

[141] Ratri Astuti, Rohlan Rogomulyo, Sri Muhartini Ikhsanah. 2012.Pertumbuhan Tanaman Dan Hasil Umbi Daun Dewa (Gynura Procumbens Back.) Pada Berbagai Intensitas Cahaya Dan Pemangkasan Daun. Vol 1, No 4

[142] Zuniastuti, Atik Hadiwiyoto, Suwedo Sudiyo, Rahman. 2010. Peningkatan Kualitas Minyak Daun Cengkeh (Eugenia Carryophyllata Thumb) Dari Daerah Kulon Progo Dengan Pemucatan Dan Redistilasi. Jurnal Sistem Teknik Vol 1, No 2

[143] Chodidjah Widayati, Eni Utari. 2007. Pengaruh Pemberian Air Rebusan Meniran (Phyllanthm Nirurilinn) Terhadap Gambaran Histopatologi Hepar Tikus Wistar Yang Terinduksi Ccl4. Jurnal Anatomi Indonesia Vol 1, No 2

[144] Dewi, Utari Kusuma, Saraswati, Tyas Rini. 2009. Efek Rebusan Daun Tapak Dara Pada Dosis Dan Frekuensi Yang Berbeda Terhadap Kerusakan Dan Akumulasi Glikogen Pada Hepar Mencit (Mus Musculus). Jurnal Bioma Vol. 11, No. 1 
[145] Surjantini, Raden Roro Siti Hatati, Siregar, Yusniar . 2018 . Efektifitas Air Rebusan Simplisia Daun Binahong (Anredera Cordifolia (Tenore) Steen) Untuk Penyembuhan Luka. Jurnal Penelitian Kesehatan Vol 6, No 2

[146] Perineum Pada Ibu Nifas Di Klinik Murniati Kecamatan Kota Kisaran Barat. Jurnal Penelitian Kesehatan Vol 9, No 3

[147] Puspitaningrum , Kusmita. 2014. Aktifitas Hipokolesterol Air Rebusan Jamur Kuping Hitam (Auricularia Polytricha (Month.) Sacc.) Pada Tikus Yang Diberi Diet Lemak Tinggi. Jurnal Farmasi Vol 7 No 2

[148] Khalilah K. Assagaf.Widdhi Bodhi.Paulina V. Y. Yamlean. 2015.Uji Efektivitas Ekstrak Etanol Daun Asam Jawa (Tamarindus Indica Linn.) Terhadap Penurunan Kadar Kolesterol Darah Tikus Putih Jantan Galur Wistar (Rattus Norvegicus). Jurnal Ilmiah Farmasi Unsrat Vol. 4 No. 3 Hal 59

[149] Rika Andriani. 2016. Perbedaan Mordan Asam Jawa (Tamarindus Indica Linn) Dan Jeruk Purut (Citrus Histrix) Terhadap Hasil Pencelupan Ekstrak Buah Senduduk ( Melastoma Candidium D. Don) Pada Bahan Sutra Perbedaan Mordan Asam Jawa (Tamarindus Indica Linn) Dan Jeruk Purut (Citrus Histrix) Terhadap Hasil Pencelupan Ekstrak Buah Senduduk (Melastoma Candidium D. Don) Pada Bahan Sutra. Jurnal Penelitian. Vol 5(No. 1).

[150] Gary Intan Ramadhani Dan Atiek Moesriati. 2013. Pemanfaatan Biji Asam Jawa (Tamarindus Indica L.) Sebagai Koagulan Alternatif Dalam Proses Menurunkan Kadar Cod Dan Bod Dengan Studi Kasus Pada Limbah Cair Industri Tempe. Jurnal Teknik Pomits Vol. 2, No. 1. Issn: 2337-3539 (2301-9271 Print) 